\title{
Non-Tariff Measures and Standards in Trade and Global Value Chains
}

\author{
John Beghin, Miet Maertens, and Johan Swinnen
}

\section{Working Paper 15-WP 554}

February 2015

\author{
Center for Agricultural and Rural Development \\ lowa State University \\ Ames, lowa 50011-1070 \\ www.card.iastate.edu
}

John Beghin is professorof economics, lowa State University, 383 Heady Hall, Ames, IA 50011. E-mail: beghin@iastate.edu.

Miet Maertens is associate professor and head of the division of Bioeconomics in the faculty of Bioscience Engineering at Katholieke Universiteit Leuven.

Johan Swinnen is professor of economics and director of the LICOS Center for Institutions and Economic Performance at Katholieke Universiteit Leuven..

This publication is available online on the CARD website: www.card.iastate.edu. Permission is granted to reproduce this information with appropriate attribution to the author and the Center for Agricultural and Rural Development, lowa State University, Ames, lowa 50011-1070.

The authors thank an editor and an anonymous referee for comments on an earlier draft.

For questions or comments about the contents of this paper, please contact John Beghin, beghin@iastate.edu.

Iowa State University does not discriminate on the basis of race, color, age, ethnicity, religion, national origin, pregnancy, sexual orientation, gender identity, genetic information, sex, marital status, disability, or status as a U.S. veteran. Inquiries can be directed to the Interim Assistant Director of Equal Opportunity and Compliance, 3280 Beardshear Hall, (515) 294-7612. 


\title{
Non-Tariff Measures and Standards in Trade and Global Value Chains
}

\author{
Forthcoming in Volume 7 of the Annual Review of Resource Economics \\ John C Beghin \\ Miet Maertens \\ Johan Swinnen*
}

This version: February 24, 2015

\begin{abstract}
We assess the literature on public and private quality standards and their impact in food markets, international trade, and global supply chains. We focus on their effects on welfare, trade, industrial organization, and labor markets and with special attention to the North-South context. We also attempt to better characterize when these measures constitute protectionism, a complicate task. We look at studies investigating public and private standards and across various quantitative approaches and countries. These standards have complex effects. The evidence is mixed regarding standards as catalyst for or impediment against trade and development, reflecting the complexity of these effects and their specificity to industries and countries. The analysis of standard-like nontariff measures and their impacts does not lead to sweeping prescriptions for policy reforms. We identify more modest prescriptions and make some recommendations for fruitful research directions.
\end{abstract}

Keywords: supply chain, standards, nontariff measures, SPS, NTM, trade, welfare, North-South, JEL codes: F13, F15, Q17, O19

*Beghin is Marlin Cole professor of international agricultural economics in the economics department and the Center for Agricultural and Rural Development at Iowa State University; Maertens is associate professor and head of the division of Bioeconomics in the faculty of Bioscience Engineering at Katholieke Universiteit Leuven; and Swinnen is professor of economics and director of the LICOS Center for Institutions and Economic Performance at Katholieke Universiteit Leuven. The authors thank an editor and an anonymous referee for comments on an earlier draft. Contact author: Beghin at beghin@iastate.edu. 


\section{Introduction}

We assess the literature on standard-like nontariff measures (NTMs), their alleged protectionism and political economy, and their impact in international trade and on global supply chains. We focus on their effects on welfare, trade, industrial organization and labor markets.

The motivations are several fold. There is the well-recognized emergence of public and private standards, which is concurrent to decreases in tariffs and other more conventional trade barriers. Simultaneously, there is increasing consumer perception of safety, quality, ethical and environmental attributes and concerns of due-diligence by global retailers in the wake of safety lapses with international ramifications (e.g., the recurrent melamine scandal).

Figures 1 and 2 illustrate this emergence of public standard-like NTMs. ${ }^{1}$ Figure 1 shows the annual sanitary and phyto-sanitary (SPS) notifications to the WTO over time since $2000 .^{2}$ As of September 2014, in excess of 17,000 notifications have been submitted to the WTO (WTO, 2014a). The US, China and the EU are the largest generators of these notifications, but in recent years developing countries have caught up and now issue $60 \%$ of the SPS notifications. Similarly, there has been rapid growth of technical barrier to trade (TBT) measures as shown in Figure 2 (WTO, 2014b). From 1995 to end of 2013, in excess of 17,000 notifications took place, not counting 3,000 addenda and 500 corrigenda and that by 121 WTO members. ${ }^{3}$

\section{$<$ Figures 1 and 2 about here $>$}

Systematic data on private standards are hard to find because private standards are a

\footnotetext{
${ }^{1}$ The conceptual and methodological arguments in this paper are general, but many empirical cases are from the agricultural and food sectors where standards have grown rapidly, and on which much literature has focused. 2 Policy notifications by governments are reporting requirements to the WTO to insure transparency and information dissemination to all trade partners and to give them an opportunity to ask for clarification or changes in policies not conforming to WTO rules.

${ }^{3}$ SPS measures refer to health protection measures related to humans and plants. TBT measures are technical requirements, voluntary standards and conformity assessment procedures, except when these are SPS measures. Both are considered standard-like NTMs. Addenda and corrigenda are supplemental and corrective elements to further clarify or modify a notification.
} 
complex aggregate. They vary with respect to who initiates the standards (e.g., producer standards versus buyer standards); who sets the standards (e.g., collective industry standards versus chain or firm-specific standards); who adopts the standard (e.g., farm-gate standards versus manufacturing and distribution standards); the attributes they address (e.g., product versus process standards); the visibility of the standard in the supply chains (e.g., business-to-business standards versus business-to-consumer standards); and the motivation behind the standard (e.g., risk management versus product differentiation standards) (Henson and Humphrey, 2010; McCluskey, 2007). Yet, the few indicators that are available suggest a parallel explosion of private standards. Figure 3 shows that the number of GlobalGAP-certified producers increased from 18,000 in 2004 to 112,600 in 2011 (GlobalGAP, 2014). ${ }^{4}$

Public and private standards not only differ in who introduces the standard (the government versus private or non-governmental organizations) but also in their nature - in particular related to trade. The WTO does not allow public non-product related process standards. ${ }^{5}$ However, private standards (over which the WTO has no authority) can cover a wide variety of aspects, such as labor standards, environmental standards that might not be productrelated. Even on similar criteria, private standards are often more stringent than public ones (Fulponi, 2007; McCluskey and Winfree, 2009; Vandemoortele and Deconinck, 2014).

In sum, both public and private standards are ubiquitous; their numbers are growing and they are here to stay and have potential for various trade frictions as documented by Disdier and van Tongeren (2010).

\footnotetext{
${ }^{4}$ GlobalGAP is one of the most widespread private standards (GAP refers to "Good Agricultural Practice" and the standard applies to food quality and safety). The standard was initially introduced by a group of European retailers but was later adopted globally (see www.globalgap.org).

${ }^{5}$ Product-related process standards affect the final product characteristics like organic versus conventional fruits. Non-product related process standards do not alter the final product characteristics, e.g, like a newspaper print on paper with some recycled content.
} 


\section{$<$ Figure 3 about here $>$}

Yet, despite these more stringent and more widespread standards, global agricultural trade has increased sharply during the past three decades. Moreover, the growth has been strongest where standards are most important, (i.e., in the higher value products) - which includes fruits, vegetables, seafood, fish, meat, and dairy products. In Asia and in Latin America, high-value products increased from around 20\% of agricultural exports in the 1980s to around 40\%. The process is similar, albeit slower, in Africa (Maertens et al., 2012).

The expansion of standards in trade has coincided with the growth of (foreign) investment and restructuring of the value chains. The best-documented effect is the so-called ‘supermarket revolution’ as large retail chains increasingly invested in emerging and developing countries (Dries et al., 2004; Reardon et al., 2003). Value chains became more concentrated and increasingly organized through vertical coordination (McCullough et al., 2008, Swinnen and Maertens, 2007). These processes have important implications. Increasing standards are associated with higher-value products. High-value exports entail an important potential for raising rural incomes and reducing poverty because of the high intrinsic value and laborintensive production systems (Anderson and Martin, 2005; Jaud and Kukenova, 2011).

These profound changes have triggered a substantive economic literature, much of it critical. There are two broad areas of critique. The first, which has attracted much attention of trade economists, is that standards are used for mercantilist reasons. They mainly focused on the potential or presumed protectionism of such standard-like NTMs, ignoring the potential consumer or societal benefits induced by standards. In sections 3 and 4, we review attempts to measure standard-like NTMs and their effects on welfare and trade. ${ }^{6}$ We provide a general taxonomy of approaches and discuss the key features of each. We first review the complexity

\footnotetext{
${ }^{6}$ For a review of different theoretical specifications of standards in economic models, see Swinnen et al. (2015).
} 
involved in determining the protectionism of these standard-like NTMs, in the presence of external effects and other market imperfections. Findings in the literature on the political economy of standard-like NTMs also yield ambiguous results: “over-standardization” or “understandardization” - similar to taxation or subsidization of agriculture - can occur depending on the political economy equilibria. Even though criteria can be conceived to determine whether NTMs are protectionist in this context, the empirical implementation of these criteria is daunting. Sections 3 and 4 (and the literature reviewed there) focuses mostly on public standards, which have been linked to protectionism. The critiques on private standards have concentrated more on their developmental implications, emphasizing that the poor in the world would be excluded from high standard trade and value chains. These critiques have induced a rapidly growing literature to assess these effects. In section 5, we review studies that focus on the impact of standards on the industrial organization and rent distribution of value chains and on smallholders, poverty and local labor markets.

Finally in section 6, we distill pragmatic and relevant policy implications and recommendations for fruitful research directions to contribute to a better understanding of the impact of standards on allocative efficiency, welfare, and supply chains, in the North-South context.

\section{The Protectionism of NTMs: Conceptual Issues and Basic Indicators}

The near explosion of standard-like NTMs in recent years brings the questions whether NTMs are used for protectionist purposes, especially in the context of commitments to decrease or eliminate tariffs and expand imports under tariff-rate-quota schemes following multiple multilateral and preferential trade agreements (Bacchetta and Beverelli, 2012). How can one 
determine if a standard-like NTM is protectionist?

Conceptually, determining protectionism of standard-like NTMs is clear as defined by Baldwin (1970), or Fisher and Serra (2000), with some limitations highlighted in Marette (2014), and Marette and Beghin (2010). Consider a social planner addressing an externality in an open economy context with domestic and foreign firms competing for the domestic market. The optimum policy to address the external effect should maximize world/global welfare (Baldwin, 1970). Deviation from the (feasible) optimum choice of policy instrument (Marette, 2014) or optimum level of a given instrument will be protectionist (Fisher and Serra, 2000). This includes policies that maximize domestic welfare because it excludes foreign firms’ profit (Fisher and Serra, 2000).

However, the optimum policy to maximize domestic welfare (as opposed to global welfare) is not necessarily protectionist (Marette and Beghin, 2010). It depends on the relative ability of domestic and foreign industries to comply with the corrective policy. A similar result comes out of the political economy literature: lobbying of domestic firms and consumers may lead to standards being set "too low" or "too high" in the political equilibrium, depending, among other things, on relative costs of compliance (Swinnen and Vandemoortele, 2008, 2009, and 2011). Needless to say the complexity (or nuances) of these conceptual findings complicates the empirical measurement and its use for policy.

The empirical implementation of such protectionism concept is nearly insurmountable. First, one has to define the relevant "world" welfare, which countries, which industries, consumers in foreign countries etc. The optimum policy instrument and its level will be sensitive to the definition of global welfare and if it affects fixed costs or variable costs (Baldwin, 2000; and Marette, 2014). Second, the informational requirements to implement such concept are huge. 
One would need reliable estimates of fixed and variable cost effects of standards on industries in many countries. Heterogeneity of firms makes this requirement daunting. External effects would have to be quantifiable as well as their valuation by consumers.

In absence of a practical empirical implementation of these protectionism concepts, a few simpler tools have been used to try to gauge protectionism of standard-like NTMs.

A first approach - which one could think of "blatant” protectionism of standard-like NTMs, is using criteria set by the WTO. First, the science-based and risk assessment criteria set constitute the "science test" in Hooker and Caswell (1998). If a standard-like NTM is not addressing any market imperfection based on scientific evidence and a risk assessment (external effect, asymmetric information leading to health or environment hazard), then the policy is protectionist, except if it is set as precautionary in a legitimate way. The latter condition means that while science is being established, a restriction or policy impediment can be put in place temporarily. National treatment also provides useful guidance as differences in standard-like NTM imposed on like-products (domestic versus imported) would signal protectionism (Baldwin, 2000). ${ }^{7}$ Third, transparency has to prevail and trade partners have to be notified of and consulted about the policy in a predictable manner. The WTO also calls for least-trade restrictive policies. ${ }^{8}$

This last criterion is more controversial because maximizing trade opportunities while addressing the external effect may not maximize welfare (Disdier and Marette, 2010; and Marette, 2014). For example, the WTO does not account explicitly for the impact of standards on consumer welfare through remaining market imperfections. Hence, economists should be queasy about this least-trade restrictive notion. One way to minimize the ambivalence is to think about

\footnotetext{
${ }^{7}$ National treatment means that imported and domestic alike products should be treated similarly.

${ }^{8}$ Least-trade restrictive mains that among available measures used to address a market imperfection, a policymaker should choose the policy that restricts trade the least.
} 
least-restrictive means (i.e., best in allocative efficiency for a given level of mitigation or internalization) as in Baldwin (2000). In addition, the WTO recommends - but does not require reliance on international standards set by CODEX and other international bodies whenever feasible. Deviations from these have to be justifiable. ${ }^{9}$ This is an easy task given that the acceptable level of risk is left to countries to define. Deviations from international standards are the basis for the "policy test" in Hooker and Caswell (1999) to identify protectionism. This is also the basis for the stringency index of protectionism in Li and Beghin (2014). ${ }^{10}$ Setting a domestic standard more stringent than the international standard is, is not a violation of WTO rules per se -it is just a deviation from a recommended practice encouraged by the WTO. However, once a standard-like NTM passes the test of the first three criteria (sciencebased, national treatment, transparency), determining protectionism beyond this criterion becomes a "wicked” empirical problem for reasons explained above. Table 1 summarizes this section.

\section{<Table 1 about here. $>$}

\section{Measurement of Standard-Like NTMs}

The literature measuring standard-like NTMs and their economic impact on trade and welfare has used various approaches to characterize them and aggregate them into some scalar indicator (Beghin, 2008).

\footnotetext{
${ }^{9}$ CODEX stands for Codex Alimentarius Commission, jointly established by FAO and WHO develops international food standards and codes of practice to protect the health of food consumers, based on science.

${ }^{10}$ Disdier and van Tongeren (2010) look at clusters of trade frictions expressed as trade concerns to the SPS and TBT Committees at the WTO to identify potential excessively stringent or costly NTMs in specific agricultural and food industries and by specific importers. They find that meat, dairy and fresh fruit and vegetables sectors tend to be highly regulated by NTMs and have high levels of trade concerns expressed by trade partners of OECD importers and therefore are prime candidates for further investigation for potential protectionism. They also find that processed product trade which is dominated by global supply chains is the least subject to concerns and NTM notifications which is consistent with limited demand for protection in these sectors.
} 
For standard-like NTMs, it is convenient to think of a framework that includes the following economic effects: (i) the "protection effect" generating potential rents to the domestic sector; (ii) the "supply cost shift" effect, from the cost of compliance with the NTM for foreign and sometimes domestic firms; and (iii) the "demand-enhancement" effect, that captures the internalization of the external effect being addressed with new information or increased safety (Josling et al., 2005). In addition, some analyses looking at the removal of the incriminated NTMs incorporate the supply shift induced by potential pest invasion induced by increased trade (Peterson and Orden, 2008; Yue et al. 2006).

Measuring standard-like NTMs is a challenge because the policy instruments involved are often dissimilar and difficult to aggregate; data are scarce for public policies and almost inexistent for private standards, except for collective standards like GlobalGAP. The measurement of a NTM is often tangled up with the quantification of its effects on market equilibrium, trade, and welfare. Many analyses use the price wedge created by the increase in the price/unit cost of imports induced by the NTM, the associated decrease in imports, the change in the own-price elasticity of import demand, the heterogeneous impacts of the NTM on trade and welfare (Deardorff and Stern, 1998; and Dee and Ferrantino, 2005).

However, most of the time, standard-like NTMs come as a set of standards and regulations and cannot be characterized by simple tax schemes. Many NTMs are bundled and do not have a simple tax-equivalent instrument or require unavailable information to be aggregated into a meaningful change of unit cost. They require more ingenious and indirect approaches to quantify their effects on variables of interest (imported quantities, price, and welfare).

Indirect and ingenious methods have been used because of scarce data, especially on consumer decisions (Beghin, 2008). Recent work in experimental economics has led to estimates 
of willingness to pay for attributes corresponding to quality standards (Van Tongeren et al. 2009). Below we review the main methods used in the literature to measure standard-like NTMS and then their impact.

\subsection{The price-wedge-ad valorem equivalent method}

This method measures the NTM regime by its impact on price. It is done by comparing the domestic price of a good relative to a reference border price of a comparable good. The tariff/tax equivalent of the regulatory regime is then used in further analysis to elucidate impacts of the NTM regime on resource allocation in the analyzed market or set of markets. Deardorff and Stern (1998) derive a large set of formulas of price-wedge equivalent for various NTM barriers. Careful applications of the price-wedge approach also account for border taxes, the cost of moving goods, and other trade costs to net them out and derive the residual effect of the NTM on the price difference. A synthetic undistorted price can be inferred using market equilibrium data and estimated price responses for supply, demand and import demand if goods are not perfect substitutes.

This tax equivalent method has shortcomings. First, most regulatory regimes include several NTMs that are aggregated into a single price effect. It is difficult to infer the price effect or allocative effects of the individual policies. Second, quality differences are often ignored but should not be. Extensions of the method have been provided by Yue et al. (2006) for imperfect substitutes, and by Liu and Yue (2013) for time-varying quality and imperfect substitutes. In the latter, the quality differential between imported and domestic good converges over time. Assumptions made on the substitution between imported and domestic goods greatly influence the price wedge equivalent. Finally, omitted trade costs may be important and the price-wedge method may falsely be inflated. 


\subsection{Inventory-based frequency and count measures}

Another type of measure simply counts the number or frequency of NTMs affecting a given market. The count is a simplistic aggregator. Presumably, the higher the count, the higher is the potential “distortion.” The measures can be used in quantitative and qualitative assessments of the incidence of NTMs. Beyond counting the number of NTMs, some investigations use indirect indicators of complexity, such as frequency of trade detentions at borders, as well as frequency and counts of incidents or requirements derived from surveys of exporters to detect discriminatory practices in international trade.

The UNCTAD database (UNCTAD) has been used by many investigations either as count or frequency to derive coverage ratios (Kee et al., 2008, Beghin et al., forthcoming). These measures are not bilateral and often do not reflect NTM integration (Disdier et al., 2014). The various measures are simple frequency of NTMs by sector, frequency ratios for product subcategories subject to at least one NTM within a more aggregate category of goods; and coverage ratio computed using the value of imports of products (within a broader category) affected by a NTM, and defined as a share of the value of that category (Disdier and van Tongeren, 2010). The latter frequency measures can be used to develop relative measures in a given country in reference to accepted best practice or observed average, for example, for SPS or food safety regulations. One can also compare frequency measures across a set of commodities or countries (Disdier et al. 2008; Fontagné et al. 2005). Large deviations from the reference (best practice or average) can be identified and these deviations signal possible protectionist issues.

NTMs vary in importance across sectors and products. Frequency and count measures assume that numerous NTMs will lead to further distortionary or allocative effects, which may not be the case in sectors characterized by potential large hazard such as food safety. Survey- 
based measures focus on perceived frictions rather than just a NTM count. They can also exhibit reporting and selection biases as not all firms answer and those who do may be inclined to report strategically to facilitate exports (see Michalek et al. 2005; Wilson and Otsuki 2004b).

\subsection{SPS stringency measures and heterogeneity index}

A stream of recent investigations have developed and used indices of stringency and heterogeneity across countries for SPS and standard-like NTMs regimes, using maximum residue limits and other policies that can be aggregated meaningfully. The latter approach goes beyond simple counts of NTMs and looks at stringency either in deviation from international standards (Li and Beghin, 2014), or from another reference value such as the highest value (Liu and Yue, 2013) to gauge unusual stringency if not protectionism. Bilateral heterogeneity of policies is also measured with the presumption that heterogeneity in regulation impedes trade (Liu and Yue, 2013; Vigani et al., 2012), especially asymmetric heterogeneity when one country is more stringent than another (DeFaria and Wieck, 2014). Several “distance” measures are used. Drogué and DeMaria use a Pearson correlation coefficient of pesticide residue limits per product between any two countries trading the product; Winchester et al. (2012) use the Gower index, which takes the sum over policies of the absolute value of the difference of policy requirements between any pair of countries, normalized by the maximum difference in the data set between any two countries. Several heterogeneity indices can be developed for different types of regulations affecting sectors and their separate effects can be assessed econometrically.

\subsection{Transparency and harmonization measures}

A set of investigations argue that (some) standard-like NTMs are necessary to address market imperfections but can be improved by more transparency or reciprocity or harmonization (Henry de Frahan and Vancauteren, 2006). Defining transparency is complex, but revolves around 
availability of information, and predictable procedures. Lejárraga et al. (2013) look at transparency provisions and their scope in an extensive series of trade agreements and develop several measures (count of transparency procedures in trade agreements, such as rules of origin or dispute settlements).

Harmonization is captured by noting which products have been harmonized within a custom union (Vancauteren, 2013; Vancauteren and Henry de Frahan, 2011). Other analyses of harmonization use deviation from ISO standards as indicator or lack thereof, or they use adherence to ISO standards and mutual recognition of certification as a "harmonized" certification mechanism (Czubala et al., 2009; Blind et al., 2013). Disdier et al. (2014) capture harmonization of NTM regulation in economic integration agreements in the context of NorthSouth trade, when Southern countries harmonize “up” to their Northern partners’ standards. In the latter investigation, dichotomic variables account for one or both countries to be member of an integration agreement and then a cascading set of dichotomic variables for agreementmember countries to reflect the presence of TBT integration, and harmonization to regional or international standards. The (dis)similarity indices reviewed in the previous section represent alternative measures of harmonization or deviations from the adoption of international standards.

\section{Trade and Welfare Effects of Standard-Like NTMs}

The measurement of the NTMs is often entangled with its trade effect, especially when NTM regulatory regimes are characterized by dummy variables. Recent econometric analyses have tried to do better in estimating trade effects. For convenience, Table 1 summarizes key points of this section. 


\subsection{Gravity-equation and related approaches}

The gravity-equation approach has been used extensively and successfully to explain bilateral trade between two countries. Trade is assumed to be proportional to economic activity (GDPs, or output of exporting industry), and decreasing in trade costs between the two countries (transport/distance, linguistic and cultural, taxes, red tape, other). Trade costs are composed of distance, remoteness, barriers, and other transactions costs with varying degrees of sophistication (Feenstra 2004).

However, the results of the gravity estimations should be interpreted with care. In general, the gravity literature on the impact of NTMs show mixed evidence depending on the direction of trade flows, the type of industries, the nature of standards and the methodology used in the analysis (Li and Beghin, 2012). Some authors find that standards are a significant source of trade restrictiveness for middle- and low-income countries (e.g., Anders and Caswell, 2009; Hoekman and Nicita, 2011; Tran et al., 2012; Wilson et al., 2003b), while others indicate that standards or their harmonization have no impact at all on developing country exports (Fontagné et al., 2005; Czubala et al., 2009; and Xiong and Beghin, 2012) or are trade expanding (Chevassus-Lozza et al., 2008; and Henry de Frahan and Vancauteren, 2006). Disdier et al. (2014) find that harmonizing to international standard is often benign or trade expanding for developing countries, whereas harmonization to regional standards is trade impeding for the same countries. The type of NTM policy instrument, which is, evaluated matters as well. Heterogeneity in GMO regulations seems to matter as well as in MRL regulations on pesticides (Vigani et al., 2012). Heterogeneity in other food-safety NTMs does not have an impact on trade in the analysis of Winchester et al. (2012). Consistently with these mixed findings, Melo et al., (2014); and Shepherd and Wilson, (2013) conclude that the 
direction and magnitude of effects on trade are sector specific and specific for different standards.

Gravity equations have obvious drawbacks. First, gravity-equation techniques estimate the trade effect of trade costs including NTMs, not their welfare impact. They ignore potential external effects or market imperfections, and thus potential welfare improvements brought by regulations that internalize negative externalities but restrict trade. Hence, the impact of NTMs on trade flows is not informative on their impact on domestic or international welfare in the presence of external effects (Baldwin, 2000; and Disdier and Marette, 2010).

Second, the direction of the effect of the "NTM" variable on trade flows is constrained to be impeding in many gravity estimations. For example, Kee et al. (2009) econometrically estimate the trade impacts of various NTMs including TBTs for a large number of sectors and countries. Then they recover the ad valorem tax equivalent (AVE) of these NTMs using corresponding own-price elasticities of import demand estimated in Kee et al. (2008). However, despite this sophisticated approach, their econometric estimation constrains the NTMs to be trade reducing, and not a trade facilitation device that could enhance excess demand. Beghin et al. (forthcoming) use the same data set to estimate unconstrained AVEs of the technical barrier to trade component of the dataset. They find that 39\% of the product lines affected by TBT-like NTMs exhibit negative AVEs, equivalent to a net-trade expansion induced by these measures.

Third, the careful measurement of the effects of NTMs relies on decomposing trade cost (the price wedge between export source and import destination) into components of transportation cost, taxes, tariffs, NTMs and other transaction costs such as language barriers. Earlier investigations (e.g., Otsuki et al., 2001on aflatoxin MRLs) did not include tariffs but used fixed effects to account for them. As tariffs have been changing over time, this is not the best 
solution. This approach has prevailed in many gravity papers, unfortunately. Tariff data are now widely available. Improvements in measurement of distance and cost of transportation have occurred recently in gravity equation estimation, and can better identify the NTM component of trade cost, relative to the impact of transportation cost or other trade costs in domestic markets (Hoekman and Nicita, 2011). Future research should decompose the export supply and import demand effect of the standards, rather than just focusing on net trade. The former is better suited for welfare analysis (Xiong and Beghin, 2014)

Fourth, many gravity based analyses of NTMs cover multiple commodities/sectors, countries, and NTM regulations. Such approach provides a gross assessment and can address general hypotheses such as the effect of these NTMs or their harmonization on net bilateral trade. The number of observations required for econometric estimation often limits the ability to look at specific cases (a policy affecting a commodity). Pooling commodities, countries, and policies greatly facilitate the minimum data requirements for econometrics, but what is gained in generality and degree of freedom gets lost in the lack of relevant policy prescriptions. In a few cases, the gravity equation has been used to look at specific policy issues such as the EU aflatoxin, GMO policy, or antibiotic residues (Otsuki et al., 2001; Disdier and Marette, 2010; Xiong and Beghin, 2012; Vigani et al., 2012).

Finally, the final-demand approach underlying most gravity specifications is questionable for intermediate demand, especially in agricultural markets. Agricultural goods are often the first input in a long value-added chain towards a final good. Some recent NTM investigations attempt to capture the intermediate nature of trade in agricultural goods like seeds or animal products (Jayasinghe et al., 2010; and Ghazalian et al., 2012). 


\subsection{Partial equilibrium analysis}

This approach focuses on key components of welfare or cost/benefit analysis of a specific set of policies affecting a single or small set of related markets/commodities and the associated market imperfections addressed by standard-like NTMs. These partial-equilibrium analyses rely on or extend upon other approaches to measure NTMs (tariff equivalent/price wedge, gravity/export demand estimation) to look at its impact on market allocation and potential externalities (Disdier and Marette, 2010; Peterson and Orden, 2008; Yue et al., 2006; and Yue and Beghin, 2009) and, in the context of global chains, on heterogeneous firms and labor market effects (Swinnen, 2007). This approach can also be combined with an econometric estimation of key economic responses to the regulations to analyze which are then incorporated into the model. Most of these studies incorporate the possibility of external effects introduced by trade and derive welfare effects of the prohibitive policies.

Yue et al. (2006) analyze the implications of removing SPS regulations in the Japanese apple market accounting for and estimating the imperfect substitution between local and imported apples as well as trade cost and the potential pest infestation linked to imports. The welfare gains from removing restrictive SPS policies are beneficial even when significant infestation occurs. Peterson and Orden (2008) incorporate seasonal effects, imperfect substitution, and risk levels in their analysis of the opening of the US avocado market to Mexican and Chilean products. They show that the opening induce net welfare gains to the US economy, even in presence of pest infestation.

Several studies have analyzed prohibitive NTM policies such as phyto-sanitary bans or excessively stringent standards chocking trade. James and Anderson (1998) analyze the Australian banana case in which policies are shown to be welfare reducing even under implausibly large 
infestation levels. Yue and Beghin (2009) analyze prohibitive Australian policies faced by NewZealand apples exporters and derive the forgone trade and associated welfare losses to Australian consumers. Orden and Romano (1996) analyze US-Mexico avocadoes markets and show that the US ban at the time was motivated by capture of the policy process by US avocado interests. The risk of infestation was small and the ban increased the US price dramatically.

\subsection{Risk assessment and cost/benefit analysis}

Risk analysis and assessment, even qualitative ones, can be combined with the previous approaches and contribute to gauging a subset of barriers, especially safety and SPS standards. The SPS agreement tends to refer to economic losses to producers and externalities, but little to consumers welfare (Wilson and Anton, 2006). Nevertheless, risk analysis even in this spirit can assess the potential protectionism of technical barriers. A negligible risk is an indication of protectionism.

However, risk is difficult to measure. Scientific knowledge or its absence is pivotal to decide if a standard-like NTM is science-based or not (the risk has been assessed or not), or if a risk is not present or is not insignificant (science could not establish a risk). The latter answer is often qualitative and is used by the WTO in its assessment of NTM and SPS regulations (Josling et al., 2005; Pauwelyn, 1999). The risk assessment combined with cost-benefit calculations provides expected net cost and benefits of the policies. Wilson and Anton (2006) conceptualize how risk assessment and production damages considerations can be extended to total welfare criteria to provide less restrictive policy menus to manage SPS risk linked to trade. These considerations had been laid down in Orden and Romano (1996).

Incomplete knowledge on risk for health or the environment that can be linked to trade and their potential economic significance is often a caveat. This lack of information can be 
overcome to some extent by multi-disciplinary approaches and collaboration with noneconomists or by borrowing from other economic fields. Recent advances in consumer valuation and willingness to pay for safer or better food have been used in international trade to analyze the effects of some NTM policies (van Tongeren et al., 2011; Disdier and Marette, 2012).

\subsection{CGE approaches}

Computable general equilibrium (CGE) models have also been used in the analysis of NTMs and SPS policies but often characterized by the shortcoming highlighted in the introduction. Economywide global analyses of the impact of the price-equivalent of NTMs are conducted by Andriamananjara et al. (2004), Fugazza and Maur (2008), and Winchester (2009). NTMs are treated as tax equivalents, but, as we explained earlier, it is not clear why the optimum NTM should be zero in the presence of market imperfections. Hence, beyond partial harmonization or

elimination of protectionist NTMs, the objective of simulating wholesale removal of these NTMs is unclear. Even harmonization, although often shown to enhance trade flows, is questionable among dissimilar trading partners (Casella, 1996; Barrett and Yang, 2001).

\subsection{Approaches using micro-data}

Another approach is to use micro-economic insights and data. These studies use firm-level data. Econometric methods are used to analyze how an increase or adoption of standards influences the export performance and productivity of individual companies.

The use of micro firm-level data to analyze the trade implications of standards is in line with the emphasis in the recent literature on firm heterogeneity in explaining international trade (Melitz, 2003; Helpman et al., 2008). For example, Chen et al. (2008) find, using the World Bank TBT survey database, that public quality standards in destination markets are positively correlated with the average export volume and with the export scope of firms in 
developing countries. Table 1 summarizes these different approaches to trade and welfare effects of NTMs.

\section{Private Standards, Value Chains, and Trade and Welfare Implications}

The lack of representative data on private standards influences the nature of the studies. Most of the studies on the impact of private standards are case-studies focusing on specific sectors, often in low- and middle-income countries. Most studies look at one specific standard or in some cases comparing multiple standards. Data to measure the effects are often from surveys specifically designed for the studies, and mostly limited to cross-sections. Regression analyses are typically used to estimate the impacts.

\subsection{Private standards and trade}

Studies find positive trade effects of compliance with private standards for firms, although some recent research contradicts these findings. Henson et al. (2011) find that certification to GlobalGAP increases firms’ export revenues for a cross-sectional sample of fresh produce exporting firms from 10 African countries. Colen et al. (2012) indicate that certification to GlobalGAP increases the length of the export season for vegetable export companies in Senegal. Volpe-Martincus et al. (2010) and Otsuki (2011) find that ISO certification improves the export performance of firms in Argentina and in Central Asia.

A major methodological problem is identifying causality. Studies based on crosssectional data are prone to overestimating the impact of standards because they fail to control for export persistence and unobserved firm characteristics. Schuster and Maertens (2013a, 2015) use 18-year panel data on asparagus export companies in Peru and find that positive effects of private standards, including GlobalGAP, on exports disappear as soon as export persistence is 
controlled for. Because they are case studies, it is not clear whether these different findings are due to methodology or to differences in sectoral and country characteristics.

\subsection{Private standards, value chains and development}

A large number of household-level studies analyze the impacts of tightening standards on poor households involved in global value chains, often as farmers or workers. Early studies warned about the dangers of marginalization of the poor with increasing standards (Reardon et al., 2001). Recent empirical studies document mixed effects of high-standards trade on exclusion of smallholders and mostly positive effects on household and farm income (Rao et al., 2012; Miyata et al., 2009); reduced risk and income variability (Ramaswami et al., 2009); farm productivity (Rao and Qaim, 2011); technology adoption and quality of produce (Dries and Swinnen, 2004); poverty alleviation (Maertens and Swinnen, 2009); and food security (Minten et al., 2009).

To understand the mechanisms of how these welfare effects arise - and about the extent to which these effects can be attributed to standards - it is important to understand how standards affect the organization and structure of supply chains. Standards and NTMs can profoundly change the structure and organization of value chains. Standards reduce transaction costs in the chain because they reduce information asymmetries between buyers and suppliers about quality, safety and other product characteristics (Hudson and Johnson, 2003; Jaffee and Masakure, 2005). On the other hand, standards increase fixed production costs and transaction costs related to conformity assessment (or shift those costs from buyers to suppliers) and thereby create economies of scale and advantages for larger suppliers (Gibbon, 2003; Dolan and Humphrey, 2000; Maskus et al., 2005). This is a concern for agri-food value chains in low- and middleincome countries with a larger number of small and poor farms where implicit norms about food 
quality and safety in the local market differ substantially from the quality and safety standards that prevail in international markets (Henson and Jaffee, 2008; Henson and Humphrey, 2010; Reardon et al., 2009).

Compliance with increasingly complex and stringent food standards and monitoring of this compliance throughout the supply chain requires tighter vertical coordination. Also upstream in the supply chain, in the relations between producers and processing or exporting companies, there is a move towards vertical coordination and contract-farming, and towards complete ownership integration and large-scale estate farming. Tighter forms of coordination facilitate monitoring of compliance with standards and reduce transaction costs in high-standards trade. Especially in low and middle-income countries, where factor markets are highly imperfect, vertical coordination is imperative for adoption of high standards. As Swinnen and Vandeplas (2011) put it, vertical coordination is importantly driven by the combined effect of standards and local market imperfections, preventing local suppliers to invest in technology and quality production processes without support from their buyers in contract-farming schemes.

In the rest of this section we assess the literature on standards and smallholder in/exclusion and on the welfare implications of standards for farmers and workers. A summary is in Table 2.

\section{<insert Table 2 about here $>$}

\subsection{Standards and smallholder in/exclusion}

Numerous empirical studies analyze whether smallholders and family farms are increasingly excluded from value chains as a result of increasing standards in international markets and highincome market segments. Most of these studies focus on a specific sector. Some studies look at one specific value chain; related to one company or supermarket; others use a sector-wide approach. Much-discussed cases are the fruit and vegetable export sectors in Kenya and Senegal 
where large shifts from smallholder to large-scale (vertically integrated) farming have been documented (Dolan and Humphrey, 2000; Gibbon, 2003; Jaffee and Masakure, 2005; Maertens and Swinnen, 2009; Ouma, 2010). The share of export produce from smallholders decreased from almost $100 \%$ to less than $50 \%$ with standards becoming more important. Similar changes are observed in Latin-America (Reardon and Berdegué, 2002; Berdegué et al., 2005), other African countries (Gibbon, 2003; Weatherspoon and Reardon, 2003; Unnevehr, 2000; Supervie and Vagneron, 2013), Asia (Belton et al., 2011) and Russia (Dries et al., 2009). In most of these cases there is only a partial shift towards large suppliers and sourcing remains partially from smallholders. Henson et al. (2013) and World Bank (2005) point to a complementary rather than a competitive relationship between company own-farm production and sourcing from smallholder farmers. An exception is the tomato export sector in Senegal that is completely based on exporter-owned agro-industrial production (Maertens et al., 2012).

Yet, there are also cases where specific contract-farming schemes for high-standard export or supermarket retail include a large number of smallholder farms. This is documented for example for the horticulture sector in Africa (Henson et al., 2005; Minten et al., 2009); for the horticulture sector and for animal production in Asia (Gulati et al., 2007; Roy and Thorat, 2008; Wang et al., 2009), and for the dairy sector in Eastern Europe (Dries et al., 2009; Noev et al., 2011). Among smallholders, those supplying to high standard value chains are often those who are somewhat larger, more capitalized and more commercially oriented, as documented by Asfaw et al. (2010b), Handschuch et al. (2013), Hernandez et al. (2007), Kersting and Wollni (2012), Maertens and Swinnen (2009), and Neven et al. (2009).

The studies have limitations and shortcomings. First, there are obvious causality issues deriving from the cross-section data sets that are often used, and questions whether other factors 
are sufficiently accounted for. Second, many studies either look at standards in general, pooling different types of standards without differentiating, or look at specific individual private standards and certification schemes. But standards are heterogeneous and the type of standard may matter (Henson and Humphrey, 2010). A few studies have used panel data methods and/or have distinguished between standards. For example, Schuster and Maertens (2013b) use panel data methods to analyze the impact of different types of private standards on the sourcing behavior of asparagus export companies in Peru. They find that especially pre-farmgate or production standards, such as GlobalGAP, decrease the share of produce that export firms source from smallholders. Van Herck and Swinnen (2014) use panel data on dairy value chains in Bulgaria and find that the dramatic reduction in smallholder supplies is not due to standards but due to other economic factors.

In summary, the evidence suggests that the effects of standards on the supplier base of the value chains are sector, country and standard specific. Despite the methodological shortcomings and difficulty of causal identification, evidence suggests that in several sectors and countries, standards induce the increased importance of large-scale and vertically-integrated production, but in other countries and sectors small farms remain dominant. To explain these different patterns of smallholder inclusion, Vandemoortele et al. (2012) develop a formal theoretical model of the emergence of the demand for high quality and safe food and analyze, which small producers are most likely to be included. They show that conditional on the initial production structure in the economy, the nature of transaction costs, and the possibility of contracting between producers and processors, certain producers are included in the high-quality economy, and others are not. Their model predicts that in a mixed production structure, with both smallholder farms and larger farm enterprises, smallholders are more likely to be excluded. 
When the farm sector is more homogeneous and dominated by small farms, it is likely that the emergence of high-standard production will be slower but more inclusive. These predictions/arguments correspond to the conclusions by Reardon et al. (2009) who, based on the existing empirical studies, find that smallholders are especially excluded if sourcing from large farms is an option.

The model also shows that reducing specific transaction costs (for example by investments in infrastructure, producer associations, third party quality control) can enhance the integration of small and less efficient producers in high-value value chains. However, this seems inconsistent with other sector studies that point at large small farmer inclusion in sectors without external support. A crucial component here is a private sector driven vertical coordination. Some empirical studies have pointed out that the inclusion of smallholder farms in high-standards trade and the adoption of private standards by smallholders is only possible with external support from development programs, public - private partnerships or collective action (e.g., Henson et al., 2011; Boselie et al., 2003; Kersting and Wollni, 2012; Narrod et al., 2009; and Okello et al., 2011).

\subsection{Standards and smallholder welfare}

The welfare of small producers who are included in high standard value chains typically improves. Some empirical studies find very large effects. Maertens and Swinnen (2009) find that farmers’ incomes double as a result of being included in the horticultural export chain in Senegal; and Dedehouanou et al. (2013) point out that this increases farmers' subjective wellbeing or happiness. Rao and Qaim (2011) and Rao et al. (2012) find that the participation of smallholder vegetable farmers in high-standard supermarket channels in Kenya increases farm productivity by $45 \%$ and farmers' incomes by $48 \%$, and this income gain results in poverty 
reduction. Minten et al. (2009) find that inclusion in a contract-farming scheme for high-standard vegetable export production in Madagascar increases farmer's incomes and their income stability, improves farm technologies and reduces the number of hungry months. Dries and Swinnen $(2004,2010)$ find that participation of small-scale farmers in contract-farming schemes in dairy value chains in Poland increases access to credit, technology and farm investment. Similar results have been documented by Gow et al. (2000), Noev et al. (2009), World Bank (2005), Negash and Swinnen (2013).

Important channels of effects and reasons for (significant) increases in farmers' incomes are technology transfers, and access to more and better inputs through vertical coordination in value chains. A second factor is that the enforcement of standard-induced vertical coordination schemes induces "efficiency premia" for farmers in the distribution of rents in the value chains, leading to income increase beyond suppliers' reservation incomes (Swinnen and Vandeplas, 2011).

While these empirical studies provide important insights on the welfare effects of inclusion in high-standards values chains, they are less informative about the pure impact of specific standards on the welfare of farmers in developing countries. The empirical studies are based on samples including a mixture of farmers in high-standards value chains and farmers in low-standards local chains. The estimated effects are confounded effects assessing the joint impact of inclusion in export or supermarket chains, of inclusion in specific chains and contractfarming schemes, and of the use of standards.

Other studies have looked at the impact of specific standards adoption on the welfare of smallholders in a more direct and un-confounded way. These studies use various econometric methods to compare adopters and non-adopters of standards within a sample of smallholders that 
are included in contract-farming schemes and export chains. This allows disentangling the effect of standard adoption from other confounding effects. The results of these studies mainly point to positive (monetary as well non-monetary) welfare effects of the adoption of GlobalGAP and a few other private standards, albeit not for all farmers. Asfaw and co-authors (2009, 2010a \& b) find that Global GAP adoption among smallholder horticultural export farmers in Kenya increases farm revenue, raises farm income and improves farmers' health (through better pesticide use). Handschuch et al. (2003) find that certification to GlobalGAP or US GAP standards among Chilean raspberry farmers doubles their incomes. Hansen and Trifkovic (2014) find that the adoption of private standards, including GlobalGAP, BAP and SQF1000, has significant positive effects on the income of medium-scale pangasius farmers in Vietnam, but no effect for small-scale farmers. Holzapfel and Wollni (2014) find that GlobalGAP certification in horticulture in Thailand has a significant positive income effect for farmers in producer-managed groups and for the largest farms but not for farmers in exporter-managed groups and for the smallest farms.

All these studies focus on one single standard and use instrumental variable or propensity score matching methods with cross-sectional data. Only one study so far distinguished between private standards. Chiputwa, et al. (2015) compare the impact of Fairtrade, organic and Utz standards on the prevalence and the depth of poverty among smallholder coffee farmers in Uganda. Using cross-sectional data and methods, they conclude that Fairtrade reduces poverty but that the other two standards have no impact.

\subsection{Labor market effects and worker welfare}

The increased reliance of value chains on large-scale plantations and vertically integrated farms instead of smallholder farms implies that more of the gains from trade in agriculture emerge 
through labor market effects (hired labor on large scale farms) instead of through product market effects. In addition, standards increase the need for labor-intensive post-harvest handling (e.g., for washing, sorting, labeling), which further increases the importance of labor market effects.

Empirical studies of these labor market effects in high-standards trade, show significant implications for rural households in developing countries. Maertens and Swinnen (2009) and Maertens et al. (2011) find that employment in large-scale horticultural export companies in Senegal (that emerged as a response to increasing standards) is well-accessible for poor and for rural women; and that this employment creates substantial income gains for rural households and results in substantial poverty reduction. Non-monetary welfare benefits of female employment include increased child schooling and reduced fertility rates (Maertens and Verhofstadt, 2014; and Van den Broeck and Maertens, 2014). Mano et al. (2011) show that employment in the cutflower export industry in Ethiopia significantly reduces poverty. Rao and Qaim (2013) point out that among smallholder vegetable farmers the demand for hired labor, especially for female labor, increases as a result of inclusion in high-standards supermarket chains in Kenya. Other recent papers are more doubtful. For example, Trivkovic (2014) finds no effect of employment in estate pangasius farms in Vietnam on the welfare of workers (using per capita consumption expenditures as measure of welfare).

The increasing importance of labor market effects in high-standard value chains also implies a role for labor standards and on labor requirements incorporated in public and private food standards. Barrientos et al. (2003) find that the adoption of labor standards and codes-ofconduct (including ethical and labor standards such as ETI and SA8000, as well as more general food standards such as GlobalGAP) among African food exporting companies improves the welfare of workings, although effects are less pronounced for temporary and female workers. 
Nelson et al. (2007) point to similar findings for the adoption of social codes of conducts in the South African wine and the Kenyan cut flower industry. Ehlert et al. (2014) find that workers in GlobalGAP certified vegetable export companies in Kenya are better trained.

Other papers are less positive about the contribution that labor requirements in food standards make in improving the welfare of workers in food export companies. Rijsgaard and Gibbon (2014) are skeptical about the contribution of labor standards (such as ETI, FLO and HEBI) in the East African cut flower sector to the empowerment of labor organizations and trade unions. Schuster and Maertens (2014) find that standards with a main focus on labor conditions (including SA8000, OHSAS18000, SEDEX, ETI and BSCI, among others) do improve the labor conditions of workers in the Peruvian horticultural export industry somewhat - for example lowering the probability of receiving a wage below the minimum wage - but not beyond national labor laws. They find that other food standards that include some requirements on labor and working conditions (including GlobalGAP and Tesco’s Nurture, among others) hardly have an impact on the conditions of workers.

\section{Policy and Research Implications and Conclusions}

The rapid growth of public and private standards has induced a large literature on their trade and development effects. Much of the international trade literature on standard-like NTMs has treated NTMs as pure trade barriers equivalent to ad valorem taxes and looking at their removal as being welfare enhancing, without considering market imperfections such as asymmetric information and externalities. Taking these market imperfections into account, NTMs have an ambiguous effect on welfare. Therefore standard-like NTMs are a challenge for the profession because there is no blanket policy recommendation paralleling those on tariffs or quotas. Sorting 
out the protectionism of standard-like NTMs is complex once one moves beyond the robust and simple detection strategy outlined in this paper. Policy prescriptions on standard-like NTMs depend on the particular context of the case analyzed.

The relevant policy debate is about sorting the NTMs that are essential from those that are inefficient and protectionist and on how to make NTMs more transparent. Further, policy making bodies should also focus on increasing compatibility of NTMs across trading nations via reciprocity, equivalence, or mutual recognition, and certifications of international standards. Redundancies among NTMs could be identified and eliminated along value chains using publicprivate partnerships, such as “value/supply-chain councils” proposed by Hoekman (2013). Global value chains are important engines of wealth creation and policy making should recognize the interconnected nature of these chains and associated NTM policies and regulations (Hoekman, 2014). Finally, policy design should also focus on how to minimize opportunities for rent-seeking to manipulate these NTMs, especially in the North-South context.

The latter point relates to the second major discussion about standards, which is their impacts on the poor. Early studies warned about the dangers of marginalization of the poor with increasing standards. Recent studies document mixed effects of high-standards trade on exclusion of smallholders and mostly positive effects on household and farm income, reduced risk and income variability, farm productivity, technology adoption and quality of produce, poverty alleviation and food security. To understand the mechanisms through which these welfare effects arise, it is important to understand how standards affect the organization and structure of value chains, and in particular the endogeneity of vertical coordination.

There is much room for improvement of research in this field. We have identified a series of weaknesses of studies and methodologies that are currently used. Namely, they are the 
systematic consideration of potential market imperfections, better characterization of NTM regimes, their potential protectionism, and the interface between public and private standards, among others.

Public and private NTMs are a full-fledged challenge to applied economists, from finding data about them, to characterizing NTM regimes accurately along supply chains and consumers markets, to analyzing their various impacts. The promising route is the partial-equilibrium one capturing the potential market imperfections, the political economy and the various actors affected by the policy being analyzed. Large econometric investigations covering the full gamut of NTMs and CGE model characterizations using NTMs AVEs will remain gross if not misleading exercises.

Further, there is evidence that other trade costs along supply chains matter greatly and might be more important than these NTM standards. Countries in the South with deficient infrastructure (from roads to ports to business climate) present a daunting barrier to exports, which deserves further "unpacking” into actionable policy recommendations.

The interface between private and public standards is another topic worthy of further investigation. Supply chains across continents have to meet private standards (in addition to collective private standards), of which we know little because they are often proprietary. Their function is to insure that stipulated quality is met and that expected health and sustainability risks have been minimized to preserve reputation and establish due diligence.

There is also a need to better integrate the NTM-type studies with micro-survey based studies to link the contributions from both and arrive at integrated conclusions. Micro studies are useful for identifying structural changes in value chains and their effects but it is difficult to draw general conclusions from the case study-type analyses. 
Most of the studies on the impact of private standards are case-studies using cross-section data and regression techniques. Obviously the use of panel data and possible experimental methodologies should improve on the identification and measurement of causal effects. Also, to derive more general conclusions about the welfare and poverty impacts of standards, more wellorganized comparative studies on multiple standards or multiple sectors would be useful.

\section{References}

Anders, S.M., and J.A. Caswell. 2009. "Standards as barriers versus standards as catalysts: Assessing the impact of HACCP implementation on US seafood imports." American Journal of Agricultural Economics 91.2: 310-321.

Anderson, Kym, and Will Martin. 2005. "Agricultural trade reform and the Doha Development Agenda." The World Economy 28.9: 1301-1327.

Andriamananjara, S., J.M. Dean, R. Feinberg, M. J. Ferrantino, R. Ludema, and M. Tsigas. 2004. "The Effects of Non-Tariff Measures on Prices, Trade, and Welfare: CGE Implementation of Policy-Based Price Comparisons." USITC Working Paper 2004-04-A.

Asfaw, S., Mithoefer, D. \& Waibel, H. 2009. EU food-safety standards, pesticide use and farm level productivity: the case of high-value crops in Kenya. Journal of Agricultural Economics 60(3), pp 645-667.

Asfaw, S., Mithöfer, D. \& Waibel, H. 2010a. Agrifood supply chain, private-sector standards, and farmers' health: Evidence from Kenya. Agricultural Economics 41(3-4):251-263.

Asfaw, S., Mithöfer, D. \& Waibel, H. 2010b. What impact are EU supermarket standards having on developing countries' export of highvalue horticultural products? Evidence from Kenya. Journal of International Food \& Agribusiness Marketing 22(3-4): 252-276.

Bacchetta, M., Beverelli, C. 2012. Non-tariff measures and the WTO, VoxEU.org, 31 July. http://www.voxeu.org/article/trade-barriers-beyond-tariffs-facts-and-challenges.

Baldwin, Richard E., 1970. Nontariff Distortions of International Trade. Washington, DC: The Brookings Institution.

Baldwin, R.E.. 2000.” Regulatory Protectionism, Developing Nations, and a Two-Tier World Trade System,” Brookings Trade Forum (pp. 237-293). Brookings Institution Press.

Barrett, C.B., and Y.N. Yang. 2001. Rational incompatibility with international product standards," Journal of International Economics 54(1): 171-191.

Barrientos, S. \& Dolan, C. \& Tallontire, A. 2003. A Gendered Value Chain Approach to Codes of Conduct in African Horticulture. World Development, 31( 9), 1511-1526,

Beghin, J.C., A.C. Disdier, and S. Marette. Forthcoming. "Trade Restrictiveness Indices in Presence of Externalities: An Application to Non-Tariff Measures." Canadian Journal of 


\section{Economics.}

Beghin, J. 2008. “Nontariff Barriers,” in S. Darlauf \& L. Blume, eds., The New Palgrave Dictionary of Economics, $2^{\text {nd }}$ Edition, Palgrave Macmillan LTD: 126-129.

Belton, B., Haque, M., Little, D. C. 2011. Certifying catfish in Vietnam and Bangladesh: Who will make the grade and will it matter? Food Policy 36 (2), pp 289-299.

Berdegué, J., Balsevich, F., Flores, L., Reardon, T., 2005. Central American supermarkets’ private standards of quality and safety in procurement of fresh fruits and vegetables. Food Policy 30 (3), 254-269.

Blind, K., A. Mangelsdorf, and J. S. Wilson. 2013. "Mutual Recognition of Accreditation: Does it Matter to Trade? Evidence from the Food, Beverage, and Tobacco Industry." Chapter 12 in J.C. Beghin (ed.). 2013. NonTariff Measures with Market Imperfections: Trade and Welfare Implications. Frontiers of Economics and Globalization Vol 12, Emerald Group Publishing.: 291-310.

Boselie, D., Henson, S., \& Weatherspoon, D. (2003). Supermarket procurement practices in developing countries: Redefining the roles of the public and the private sectors. American Journal of Agricultural Economics, 85(5), 1155-1161.

Casella, A. (1996). "Free Trade and Evolving Standards,” chapter 3 in J.N. Bhagwati and R.E. Hudec (eds.) Fair Trade and Harmonization: Prerequisites for Free Trade? MIT press.

Chen, M., Wilson, J. \& Otsuki T. (2008). Standards and Export Decisions: Firm-level Evidence from Developing Countries. The Journal of International Trade \& Economic Development , 17(4), 501-523

Chevassus-Lozza, E., Latouche, K., Majkovic, D., and Unguru, M. 2008. “The Importance of EU-15 Borders for CEECs Agri-food Exports: The Role of Tariffs and Non-tariff Measures in the Preaccession Period”. Food Policy 33(6): 595-606.

Chiputwa, B., Spielman, D., and M. Qaim (2015). Food Standards, Certification, and Poverty among Coffee Farmers in Uganda. World Development 66, pp 400-412.

Colen, L., Maertens M. \& Swinnen, J. (2012). Private Standards, Trade and Poverty: GlobalGAP and Horticultural Employment in Senegal" The World Economy. 35(8); 1073-1088

Czubala, W., B. Shepherd, and J.S. Wilson. 2009. Help or Hindrance? The Impact of Harmonised Standards on African Exports. Journal of African Economies, 18(5), pp 711-744.

Deardorff, Alan V., and Robert M. Stern. 1998. Measurement of Nontariff Barriers: Studies in International Economics. Ann Arbor MI: University of Michigan Press.

Dedehouanou, F., Swinnen, J. and M. Maertens. 2013. Does contracting make farmers happy? Evidence from Senegal. Review of Income and Wealth, vol 59(1), pp 138-160

Dee, P., and M. Ferrantino, eds. 2005. Quantitative Methods for Assessing the Effects of NonTariff Measures and Trade Facilitation. Singapore: APEC Secretariat and World Scientific Publishing Co.

de Faria, R.N, and C. Wieck. 2014. "Measuring the extent of GMO Asynchronous Approval Using Regulatory Dissimilarity Indices: The Case of Maize and Soybean. Paper presented at the EAAE 2014 Congress, August 26-29, Ljubljana, Slovenia. 
Disdier, A.C., and S. Marette. 2010. "The combination of gravity and welfare approaches for evaluating nontariff measures." American Journal of Agricultural Economics 92.3 (2010): 713726.

Disdier, A.C., and S. Marette. 2012. "How do consumers in developed countries value the environment and workers' social rights in developing countries?" Food Policy 37.1: 1-11.

Disdier, A.C., and F. van Tongeren. 2010. "Non-tariff measures in agri-food trade: What do the data tell us? Evidence from a cluster analysis on OECD imports." Applied Economic Perspectives and Policy (2010): 436-455.

Disdier, A.C., L. Fontagné, and M. Mimouni. 2008. "The Impact of Regulations on Agricultural Trade: Evidence from SPS and NTM Agreements,” American Journal of Agricultural Economics 90(2): 336-350

Disdier, A.C., L. Fontagné, and O. Cadot. 2014. "North-South standards harmonization and international trade." The World Bank Economic Review: lht039.

Dolan, C., \& Humphrey, J. 2000. Governance and trade in fresh vegetables: The impact of UK supermarkets on the African horticulture industry. Journal of Development Studies, 37(2), 147176.

Dries, L., Swinnen, J. 2010. The impact of interfirm relationships on investment: evidence from the Polish dairy sector. Food Policy, 35 (2), 121-129

Dries, L. and J.F.M. Swinnen. 2004. "Foreign Direct Investment, Vertical Integration and Local Suppliers: Evidence from the Polish Dairy Sector,” World Development 32(9): 1525-1544

Dries, L., Germenji, E., Noev, N., Swinnen, J.. 2009. Farmers, vertical coordination, and the restructuring of dairy supply chains in central and eastern Europe. World Development, 37 (11), 1742-1758.

Dries, L., Reardon, T., Swinnen, J. 2004. The rapid rise of supermarkets in former statecontrolled economies. Development Policy Review, 22 (5), 525-556.

Drogué, S. and F. DeMaria. 2012. Pesticides residues and trade: the apple of discord? Food Policy 37(6): 641-649.

Ehlert, C., Mithöfer, D. \& Waibel, H.. 2014. Worker welfare on Kenyan export vegetable farms, Food Policy 46: 66-73.

Feenstra, R.E. 2004. Advanced International Trade. Theory and Evidence. Princeton NJ: Princeton University Press.

Fisher, R. and P. Serra. 2000. “Standards and protection,” Journal of International Economics 52(2): 377-400.

Fontagné, L., M. Mimouni and JM Pasteels. 2005. "Estimating the impact of environmental SPS and NTM on international trade,” Integration and Trade Journal 22: 7-37.

Fugazza, M., and Maur, J.-C. 2008. Non-tariff barriers in CGE models: How useful for policy? Journal of Policy Modeling 30: 475-490.

Fulponi, L, (2007). The globalization of private standards and the agri-food system. In: J. F. M. Swinnen, ed. Global supply chains, standards and the poor. CABI publications, pp. 19-25. 
Ghazalian, P. L., L.D. Tamini, B. Larue, B., and J.P. Gervais. 2012. “A gravity model to account for vertical linkages between markets with an application to the cattle/beef sector." The Journal of International Trade \& Economic Development 21(4): 579-601.

Gibbon, P. 2003. Value-chain governance, public regulation and entry barriers in the global fresh fruit and vegetable chain into the EU. Development Policy Review, 21, 615-625.

GlobalGAP. 2014. THE GLOBALG.A.P. DATABASE.

Gow, H., Streeter, D., Swinnen, J. 2000. How private contract enforcement mechanisms can succeed where public institutions fail: The case of Juhosucor A.S. Agricultural economics, 23 (3), 253-265.

Gulati, A., Minot, N., Delgado, C. \& Bora, S. 2007. Growth in high-value agriculture in Asia and the emergence of vertical links with farmers, in Swinnen, J. F. M. ed, Global Supply Chains, Standards and the Poor (CABI publishing, Oxon).

Handschuch, C., Wollni, M. \& Villalobos, P. 2013. Adoption of food safety and quality standards among Chilean raspberry producers - Do smallholders benefit?, Food Policy, 40: 6473.

Hansen, H. \& Trifković, N. 2014. Food Standards are Good - For Middle-Class Farmers. World Development. 56(C). 226-242.

Helpman E, Melitz M, Rubinstein Y. 2008. Estimating trade flows: Trading Partners and Trading Volumes. Quartely Journal of Economics. 123(2), 441-487.

Henry de Frahan, B., and M. Vancauteren. 2006. "Harmonization of food regulations and trade in the Single Market: evidence from disaggregated data.” European Review of Agricultural Economics 33(3): 337-360.

Henson, S. \& Humphrey,J. 2010. Understanding the Complexities of Private Standards in Global Agri-Food Chains as They Impact Developing Countries. Journal of Development Studies 46(9) , 1628-1646.

Henson, S. \& Jaffee, S. 2008. Understanding Developing Country Strategic Responses to the Enhancement of Food Safety Standards. The World Economy, 31 (4), pp. 548-568.

Henson, S.S., Masakure, O., Cranfield, J. 2011. Do fresh produce exporters in sub-Saharan Africa benefit from globalgap certification? World Development 39 (3),375-386

Henson, S., Jaffee, S., \& Masakure, O. 2013. The Participation of Smallholder Farmers in HighValue Export Markets Governed by Standards: The Role of Exporter Procurement

Henson, S., Masakure, O., \& Boselie, D. 2005. Private food safety and quality standards for fresh produce exporters: The case of Hortico Agrisystems, Zimbabwe. Food Policy, 30(4), 371-384.

Hernandez, R., Reardon, T., Berdegue, J., 2007. Supermarkets, wholesalers, and tomato growers in Guatemala. Agricultural Economics 36 (3), 281-290.

Hoekman, B. and A. Nicita, 2011. “Trade Policy, Trade Costs, and Developing Country Trade,” World Development 39(12): 2069-2079.

Hoekman, B. 2013. “Adding Value,” Finance and Development 50(4) December: 22-24.

Hoekman, B. 2014. "Supply chains, mega-regionals and multilateralism: a road map for the 
WTO.” Robert Schuman Centre for Advanced Studies Research Paper No. RSCAS, 27.Holzapfel, S. and M. Wollni (2014). Is Global-GAP Certification of Small-scale Farmers Sustainable? Evidence from Thailand. Journal of Development Studies 50 (5), pp 731-747.

Hooker, Neal H., and Julie A. Caswell. 1999. "A Framework for Evaluating Non-Tariff Barriers to Trade Related to Sanitary and Phytosanitary Regulation." Journal of Agricultural Economics 50.2: 234-246.

Hudson, J., \& Jones, P. 2003. International Trade in 'Quality Goods': Signaling Problems for Developing Countries. Journal of International Development 15 , 15; 999-1013.

Jaffee, S \& Masakure, O. 2005. Strategic Use of Private Standards to enhance international competitiveness: Vegetable Exports from Kenya and Elsewhere. Food Policy 30(3), 316-333.

James, S., and K. Anderson. 1998. "On the need for more economic assessment of quarantine policies.” Australian Journal of Agricultural and Resource Economics, 42(4): 425-444.

Jaud, M. \& Kukenova, M. 2011. Financial development and survival of African agri-food exports. Policy Research Working Paper Series 5649, The World Bank.

Jayasinghe, S., J. C. Beghin, and GC. Moschini. 2010. "Determinants of world demand for US corn seeds: the role of trade costs." American Journal of Agricultural Economics 92.4: 999-1010.

Josling, T., D. Roberts, and D. Orden. 2004. Food Regulation and Trade: Towards a Safe and Open Global System. Institute for International Economics, Washington DC.

Kee, H.L., A. Nicita, and M. Olarreaga, 2008. "Import Demand Elasticities and Trade Distortions,” Review of Economics and Statistics 90(4): 666-682.

Kee, H.L., A. Nicita, and M. Olarreaga, 2009. “Estimating Trade Restrictiveness Indices,” The Economic Journal 119: 172-199.

Kersting, S., \& Wollni, M., (2012). New institutional arrangements and standard adoption: evidence from small-scale fruit and vegetable farmers in Thailand. Food Policy . 37 (4), 452462.

Lejárraga, I., B. Shepherd, and F. van Tongeren, 2013. “Transparency in Nontariff Measures: Effects on Agricultural Trade,” chapter 4 in J.C. Beghin (ed.) op citum: 99-125.

Li, Y., and J.C. Beghin. 2012. A meta-analysis of estimates of the impact of technical barriers to trade." Journal of Policy Modeling 34.3: 497-511.

Li, Y., and J.C. Beghin. 2014. "Protectionism indices for non-tariff measures: An application to maximum residue levels." Food Policy 45: 57-68.

Liu, L., and C. Yue. 2013. "Investigating the Impact of MRL Standards’ Similarity on Trade." Chapter 6 in J.C. Beghin (ed.), op citum: 151-164.

Maertens, M., and J.F.M. Swinnen. 2009. "Trade, standards, and poverty: Evidence from Senegal." World Development 37.1: 161-178.

Maertens, M. and E. Verhofstadt. 2013. Horticultural exports, female wage employment and primary school enrolment: Theory and evidence from Senegal. Food Policy, Vol 43, pp 118-131.

Maertens, M., Minten, B., \& Swinnen, J. 2012. Modern Food Supply Chains and Development: Evidence from Horticulture Export Sectors in Sub-Saharan Africa. Development Policy Review , 
30 (4): 473-497.

Maertens, M., Colen, L., Swinnen, J. 2011. Globalization and poverty in Senegal: a worst case scenario? European Review of Agricultural Economics, 38 (1), 31-54.

Mano, Y., Yamano, T., Suzuki, A. \& Matsumoto, T. 2011. Local and personal networks in employment and the development of labor markets: Evidence from the cut flower industry in Ethiopia, World Development 39(10): 1760-1770.

Marette, S. 2014. "Non-Tariff Measures when Alternative Regulatory Tools can be Chosen." Mimeo.

Marette, S., and J. Beghin. 2010. "Are standards always protectionist?" Review of International Economics 18.1:179-192.

Maskus, K. E., Otsuki, T., \& Wilson, J. S. 2005. The Cost of Compliance with Product Standards for Firms in Developing Countries: An Econometric Study. World Bank Policy Research Working Paper 3590.

McCluskey, J. J. 2007. Public and private food quality standards: Recent trends and strategic incentives. In Swinnen (ed.) Global supply chains, standards, and the poor, CABI: 19-25.

McCluskey, J. J., \& Winfree, J. A. 2009. Pre-empting public regulation with private food quality standards. European Review of Agricultural Economics 36(4): 525-539.

McCullough, E., Pingali, P. \& Stamoulis, K. 2008. The Transformation of Agri-Food Systems: Globalization, Supply Chains and Smallholder Farmers. London, UK: Earthscan Ltd., 416 pp.

Melitz, M. J. 2003. The Impact of Trade on Intra-Industry Reallocations and Aggregate Industry Productivity. Econometrica , 71(6), 1695-1725.

Melo, Oscar, Alejandra Engler, Laura Nahuehual, Gabriela Cofre, and José Barrena. 2014. "Do Sanitary, Phytosanitary, and Quality-related Standards Affect International Trade? Evidence from Chilean Fruit Exports." World Development 54: 350-359.

Michalek, J., J. Hagemejer, V. Roshal, J. Rothert, A. Tovias, A. Pugacewicz, and M. Vancauteren. 2005. "Comparative analysis of importance of technical barriers to trade (NTM) for Central and Eastern European Countries’ and Mediterranean Partner Countries' exports to the EU,” FEMISE Research no. FEM 22-03.

Minten, B., Randrianarison, L. \& Swinnen, J. F. M. 2009. Global retail chains and poor farmers: Evidence from Madagascar. World Development 37(11): 1728-1741.

Miyata, S., Minot, N., and Hu, D. 2009. Impact of Contract Farming on Income: Linking Small Farmers, Packers, and Supermarkets in China. World Development, 37(11), 1781-1790.

Narrod, C., Roy, D., Okello, J., Avendano, B., Rich, K., \& Thorat, A. 2009. Public-private partnerships and collective action in high value fruit and vegetable supply chains. Food Policy, 34(1), 8-15.

Negash, M. and J. Swinnen. 2013. Biofuels and Food Security: Micro-Evidence from Ethiopia. LICOS Discussion Paper DP319.

Nelson V., Martin A. \& Ewert J. 2007. The Impacts of Codes of Practice on Worker Livelihoods. Empirical Evidence from South African Wine and Kenyan Cut Flower Industries. Journal of Corporate Citizenship. 28; 61-72 
Neven, D., Odera, M., Reardon, T. \& Wang, H. 2009. Kenyan supermarkets and emerging middle-class horticulture farmers. World Development 37(11): 1802-1811 .

Noev, N., Dries, L., Swinnen, J. 2009. Institutional change, contracts, and quality in transition agriculture: evidence from the Bulgarian dairy sector. Eastern European Economics, 47 (4), 6285.

Okello, J., Narrod, C., \& Roy, D. 2011. Export standards, market institutions and smallholder farmer exclusion from fresh export vegetable high value chains: experiences from Ethiopia, Kenya and Zambia. Journal of Agricultural Science, 3(4), 188-195.

Orden, D., and E. Romano. 1996. "The Avocado Dispute and Other Technical Barriers to Agricultural Trade Under NAFTA," Invited paper presented at the conference "NAFTA and Agriculture: Is the Experiment Working," San Antonio, TX. November.

Otsuki, T. 2011. Effect of International Standards Certification on Firm-Level Exports: An Application of the Control Function Approach, OSIPP Discussion Paper 11E005, Osaka School of International Public Policy, Osaka University.

Otsuki, T., J.S. Wilson, and M. Sewadeh. 2001. "What Price Precaution? European Harmonisation of Aflatoxin Regulations and African Groundnut Exports.” European Review of Agricultural Economics 28(3):263-283.

Ouma, S. 2010. Global Standards, Local Realities: Private Agrifood Governance and the Restructuring of the Kenyan Horticulture Industry. Economic Geography 86(2), pp 197-222.

Pauwelyn. J. 1999. The WTO agreement on sanitary and phytosanitary (SPS) measures as applied in the first three SPS disputes. EC-Hormones, Australia-salmon and Japan-varietals," Journal of International Economic Law 2(4):641-664.

Peterson, E.B., and D. Orden. 2008. "Avocado pests and avocado trade." American Journal of Agricultural Economics 90.2: 321-335.

Ramaswami, B., Birthal, P.S. and P.K. Joshi. 2009. Grower heterogeneity and the gains from contract farming: the case of Indian poultry. Indian Growth and Development Review, 2(1), pp 56-74

Rao, E. and M. Qaim. 2011. Supermarkets, Farm Household Income, and Poverty: Insights from Kenya. World Development 39(5), pp 784-796.

Rao, E. and M. Qaim. 2013. Supermarkets and agricultural labor demand in Kenya: A gendered perspective. Food Policy 38, pp 165-176.

Rao, E., Brummer, B. and M. Qaim. 2012. Farmer Participation in Supermarket Channels, Production Technology, and Efficiency: The Case of vegetables in Kenya. American Journal of Agricultural Economics 94(4): 891-912;

Reardon, T. \& Berdegué, J. 2002. The Rapid Rise of Supermarkets in Latin America: Challenges and Opportunities for Development. Development Policy Review 20(4): 371-88.

Reardon, T., Barrett, C., Berdegué, J. A., \& Swinnen, J. 2009. Agrifood industry transformation and small farmers in developing countries. World Development, 37(11), 1717-1727.

Reardon, T., Codron, J. M., Busch, L., Bingen, J., \& Harris, C. 2001. Global change in agrifood grades and standards: agribusiness strategic responses in developing countries. International 
Food and Agribusiness Management Review, 2 (3-4), 421-435.

Reardon, T., Timmer, C.P., Barrett, C. and J. Berdegué. 2003. “The Rise of Supermarkets in Africa, Asia, and Latin America,” American Journal Agricultural Economics 85(5): 1140-1146.

Riisgaard, L. \& Gibbon, P. 2014. Labour Management on Contemporary Kenyan Cut Flower Farms: Foundations of an Industrial-Civic Compromise. Journal of Agrarian Change, 14: 260285.

Roy, D. and A. Thorat. 2008. Success in High Value Horticultural Export Markets for the Small Farmers: The Case of Mahagrapes in India. World Development 36(10), pp 1874-1890.

Schuster, M. \& Maertens, M. 2013a. Private Food Standards and Firm-Level Trade Effects: A Dynamic Analysis of the Peruvian Asparagus Export Sector. Chapter 8 in Beghin J.C. (ed.), op citum.: 187-210.

Schuster, M., \& Maertens, M. 2013b. Do private standards create exclusive supply chains? New Evidence from the Peruvian asparagus export sector. Food Policy, 43, 291-305.

Schuster, M., \& Maertens, M. 2015. The Impact of Private Food Standards on Developing Countries' Export Performance: An Analysis of Asparagus Firms in Peru. World Development, 66, 208-221.

Schuster, M. and M. Maertens. 2014. Do Labour Standards Benefit Agro-Industrial Workers? Bioeconomics Working Paper 2014/9.

Shepherd, B. and N.L.W. Wilson. 2013.Product standards and developing country agricultural exports: The case of the European Union. Food Policy, Vol. 42, pp 1-10.

Subervie, J., \& Vagneron, I. 2013. A drop of water in the Indian Ocean? The impact of GlobalGap certification on Lychee farmers in Madagascar. World Development.50, 57-73.

Swinnen, J.F.M., and M. Maertens. 2007. "Globalization, privatization, and vertical coordination in food value chains in developing and transition countries,” Agricultural Economics 37 (s1): 89102.

Swinnen, J., Deconinck, K., Vandeplas, A. and T. Vandemoortele. 2015. Quality Standards, Value Chains and International Development: Economic and Political Theory, Cambridge: Cambridge University Press.

Swinnen, J.F.M., and T. Vandemoortele. 2008. "The political economy of nutrition and health standards in food markets." Applied Economic Perspectives and Policy 30.3: 460-468.

Swinnen, J.F.M., and T. Vandemoortele. 2009. "Are food safety standards different from other food standards? A political economy perspective." European Review of Agricultural Economics 36.4: 507-523.

Swinnen, J.F.M., and T. Vandemoortele. 2011. "Trade and the political economy of food standards." Journal of Agricultural Economics 62.2 (2011): 259-280.

Swinnen, J., \& Vandeplas, A. 2011. Rich Consumers and Poor Producers: Quality and Rent Distribution in Global Value Chains. Journal of Globalization and Development, 2 (2), 1-30.

Swinnen, J. F.M., ed. 2007. Global supply chains, standards and the poor: how the globalization of food systems and standards affects rural development and poverty. Cabi. 
Tran, N., N.L. Wilson, and S. Anders. 2012. "Standard harmonization as chasing zero (tolerance limits): the impact of veterinary drug residue standards on crustacean imports in the EU, Japan, and North America.” American Journal of Agricultural Economics 94(2): 496-502.

Trivkovic, N. 2014. Governance Strategies and Welfare Effects: Vertical Integration and Contracts in the Catfish Sector in Vietnam. The Journal of Development Studies 50(7), pp 949961.

United Nations Conference on Trade and Development (UNCTAD). 2005. "Methodologies, Classifications, Quantification and Development Impacts of Non-Tariff Barriers. Note by the UNCTAD secretariat," document TD/B/COM.1/EM.27/2, June 23.

Unnevehr, L. J. 2000. Food safety issues and fresh food product exports from LDCs. Agricultural Economics, 23(3), 231-240.

Van den Broeck, G. and M. Maertens. 2014. Female Employment Reduces Fertility in Rural Senegal. Bioeconomics Working Paper 2014/10.

Van Herck, K. and J. Swinnen. 2014. "Small Farmers, Standards and Value Chains: Panel evidence from the Bulgarian dairy chain during EU accession”, LICOS DP, LICOS Centre for Institutions and Economic Performance, KU Leuven.

Van Tongeren, F., J. C. Beghin, and S. Marette. 2009. A cost-benefit framework for the assessment of non-tariff measures in agro-food trade. No. 21. OECD Publishing.

Vancauteren, M., and B. Henry de Frahan. 2011. Trade policy, competition and productivity: The impact of EU harmonization in the Dutch food processing industry. De Economist, 159(4), 483-509.

Vancauteren, M.. 2013. "EU harmonisation of regulations and mark-ups in the Dutch food industry." European Review of Agricultural Economics 40:1163-189.

Vandemoortele, T. and K. Deconinck, 2014. When are private standards more stringent than public standards? American Journal of Agricultural Economics, vol. 96, no. 1, pp. 154 - 171.

Vandemoortele T, Rozelle S, Swinnen J, Xiang T, 2012. Quality and Inclusion of Producers in Value Chains: A Theoretical Note. Review of Development Economics, vol. 16, no. 1, pp. 122 136.

Vigani, M., Raimondi, V., and Olper, A. 2012. "International trade and endogenous standards: the case of GMO regulations." World Trade Review 11 (3): 415-437.

Volpe Martincus, C., Castresana, S., \& Castagnino, T. 2010. ISO Standards: A Certificate to Expand Exports? Firm-Level Evidence from Argentina. Review of International Economics, 18(5); 896-912.

Wang, H., Dong, X., Rozelle, S., Huang, J. \& Reardon, T. 2009. Producing and procuring horticulture crops with Chinese characteristics: The case of Northern China. World Development 37(11): 1791-1801.

Weatherspoon, D.D. \& Reardon, T. 2003. The rise of supermarkets in Africa: Implications for agrifood systems and the rural poor. Development Policy Review 21(3):333-356.

Wilson, N.L., and J. Anton. 2006. "Combining Risk Assessment and Economics in Managing a Sanitary-Phytosanitary Risk,” American Journal of Agricultural Economics 88(1): 194-202. 
Wilson, J.S. and T. Otsuki. 2004a. "To spray or not to spray: pesticides, banana exports, and food safety,” Food Policy 29(2): 131-146.

Wilson, J.S., and T. Otsuki. 2004b. "Standards and Technical Regulations and Firms in Developing Countries: New Evidence from A World Bank Technical Barriers to Trade Survey,” The World Bank, June, preliminary draft.

Winchester, N., M.L. Rau, C. Goetz, B. Larue, T. Otsuki, K. Shutes, C. Wieck, H.L. Burnquist, M. J. Pinto de Souza, and R. Nunes de Faria. 2012. "The Impact of Regulatory Heterogeneity on Agri-food Trade." The World Economy 35, no. 8: 973-993.

Winchester, N. 2009. "Is there a dirty little secret? Non-tariff barriers and the gains from trade." Journal of policy modeling 31.6: 819-834.

World Bank. 2005. When the market comes to you -- Or not. The Dynamics of Vertical Coordination in Agri-food Chains in Transition.

World Trade Organization (WTO). 2014a. Committee on Sanitary and Phytosanitary Measures. "Overview regarding the level of implementation of the transparency provisions of the SPS Agreement” - Note by the Secretariat - Revision 7.

World Trade Organization (WTO). 2014b. Committee on Technical Barriers to Trade. "Nineteenth Annual Review of the Implementation and Operation of the TBT Agreement. Note to the Secretariat.

Xiong, B., and J.C. Beghin. 2012. ’Does European Aflatoxin Regulation Hurt Groundnut Exporters from Africa?” European Review of Agricultural Economics 39(4): 589-609.

Xiong, B., and J.C. Beghin. 2014. "Disentangling Demand-Enhancing and Trade-Cost Effects of Maximum Residue Regulations." Economic Inquiry 52.3: 1190-1203.

Yue, C., J.C. Beghin, and H.H. Jensen. 2006. "Tariff Equivalent of Technical Barriers to Trade with Imperfect Substitution and Trade Costs.” American Journal of Agricultural Economics 88(4): 947-960.

Yue, C., and J.C. Beghin. 2009. “The Tariff Equivalent and Forgone Trade Effects of Prohibitive Technical Barriers to Trade,” American Journal of Agricultural Economics 91(4): 930-941. 


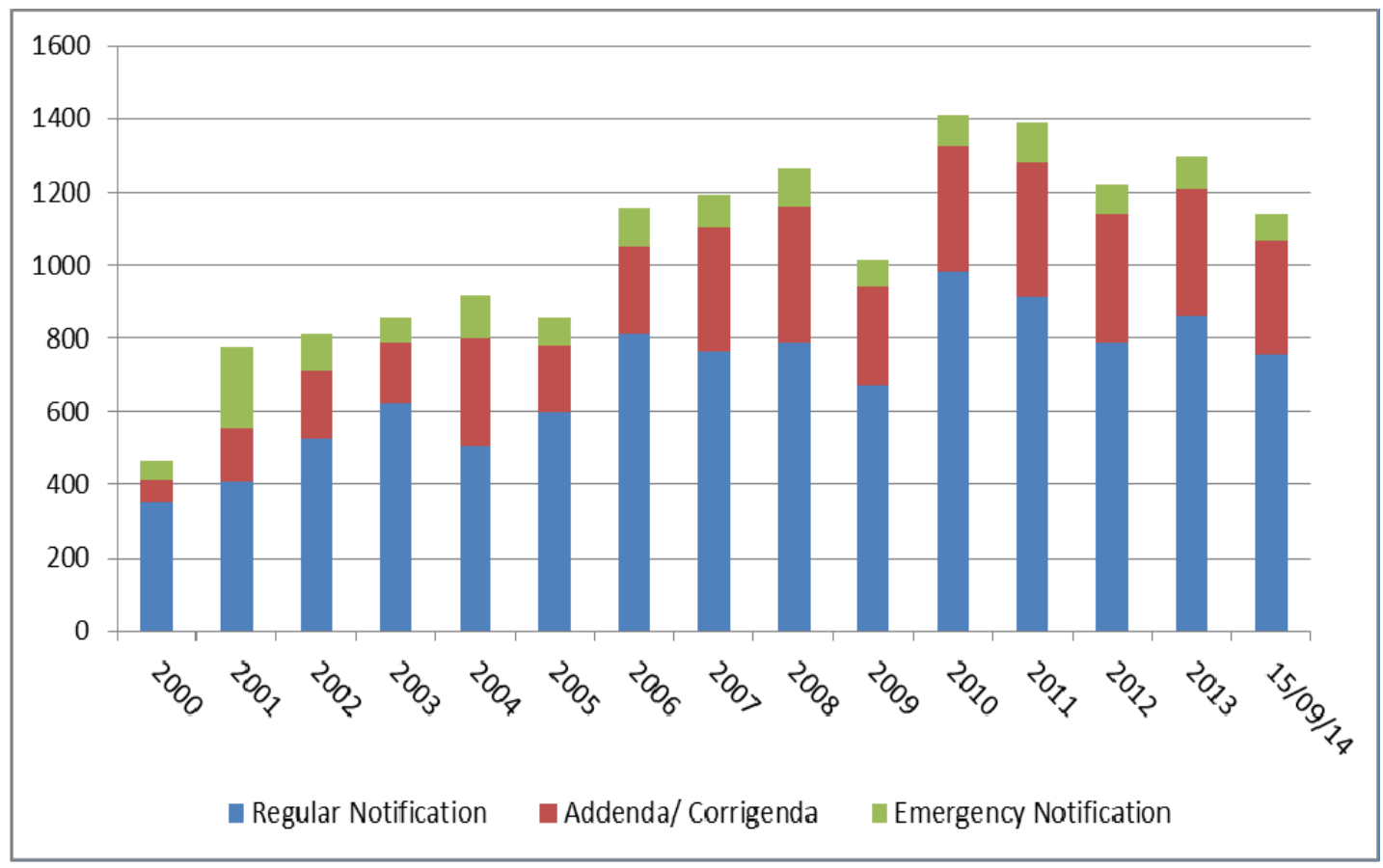

Figure 1. Annual new SPS notifications to the WTO since 2000

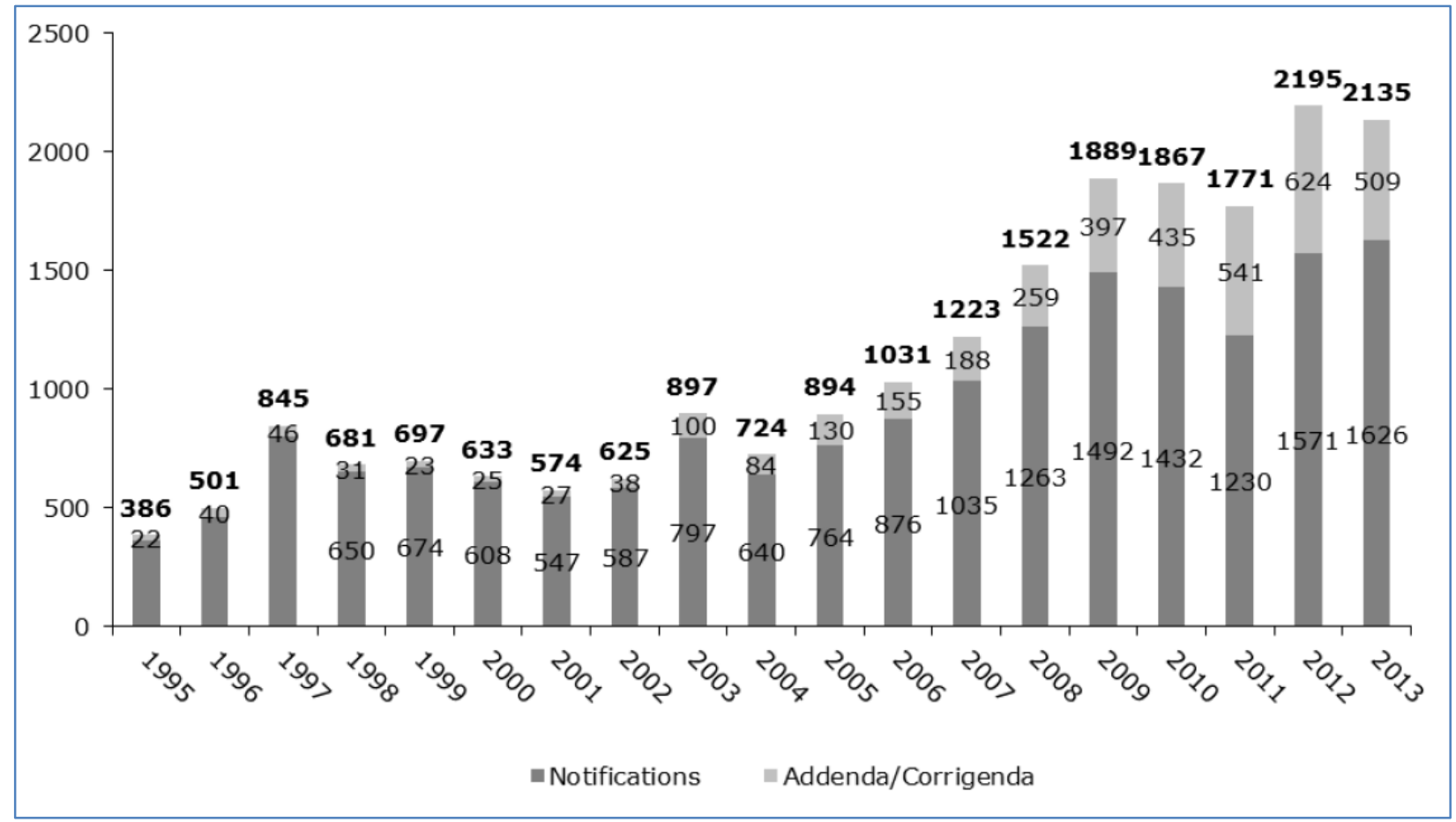

Figure 2. Annual TBT notifications since 1995 to the WTO 


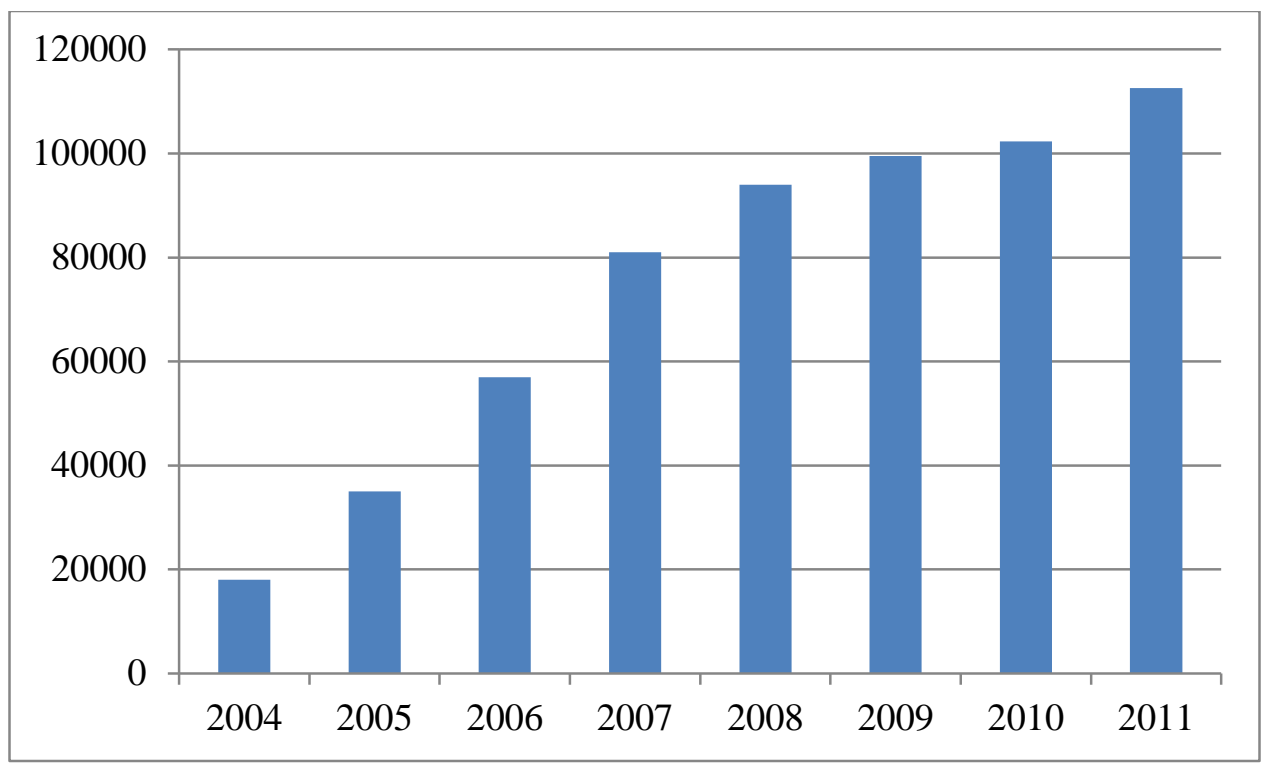

Figure 3. Number of GlobalGAP certified producers 


\section{Table 1: Summary of the literature on protectionism and trade and welfare effects of public standard-like NTMs}

\begin{tabular}{|c|c|c|}
\hline Focus and approach & Strengths / weaknesses & Examples \\
\hline \multicolumn{3}{|c|}{ Protectionism and political economy of standards } \\
\hline $\begin{array}{l}\text { Conceptual and empirical } \\
\text { papers on how to define } \\
\text { protectionism }\end{array}$ & $\begin{array}{l}\text { - clear conceptual model but difficult to } \\
\text { implement empirically } \\
\text { - criteria using WTO principles } \\
\text { - simple empirical measures using } \\
\text { deviation from international or } \\
\text { reference standards }\end{array}$ & $\begin{array}{l}\text { Conceptual: Baldwin (1970) and } \\
\text { (2000); Fisher and Serra (2000); } \\
\text { Hooker and Caswell (1999); } \\
\text { Marette (2014); Marette and Beghin } \\
\text { (2011) } \\
\text { Empirical:; Li and Beghin (2014); } \\
\text { Liu and Yue (2013) }\end{array}$ \\
\hline $\begin{array}{l}\text { The political economy of } \\
\text { endogenous standards }\end{array}$ & $\begin{array}{l}\text { - look at the under/over provision } \\
\text { relative to social planner }\end{array}$ & $\begin{array}{l}\text { Swinnen and Vandemoortele } \\
\text { (2008) (2009) and (2011) ; Vigani } \\
\text { et al. (2012); }\end{array}$ \\
\hline \multicolumn{3}{|c|}{ Estimates of NTM impact on bilateral trade across nations } \\
\hline $\begin{array}{l}\text { Large econometric studies } \\
\text { using panel or cross sections } \\
\text { of countries, many sectors, } \\
\text { using simple proxies of total } \\
\text { NTM regimes in gravity- } \\
\text { type models } \\
\text { Large CGE models relying } \\
\text { on AVES of NTMs }\end{array}$ & $\begin{array}{l}\text { - typically abstracts from market } \\
\text { imperfections } \\
\text { - includes and identifies several sources } \\
\text { of trade costs } \\
\text { - broad brush; Mixed evidence on NTM } \\
\text { trade cost } \\
\text { - cannot explain why estimated NTM } \\
\text { could be trade-enhancing }\end{array}$ & $\begin{array}{l}\text { Econometric: Hoekman and Nicita } \\
\text { (2011); Kee et al. 2009; Li and } \\
\text { Beghin (2012); Beghin et al. } \\
\text { (forthcoming); } \\
\text { CGE models: Andriamananjara et } \\
\text { al (2004); Fugazza and Maur } \\
\text { (2008); Winchester (2009) }\end{array}$ \\
\hline $\begin{array}{l}\text { Sector or policy specific } \\
\text { econometric studies of } \\
\text { standard-like NTMs with } \\
\text { cross-section or panels of } \\
\text { countries and subsectors }\end{array}$ & $\begin{array}{l}\text { - more detailed and focused on specific } \\
\text { NTMs } \\
\text { - cross-sectional and panel data based } \\
\text { evidence } \\
\text { - looks at heterogeneity, harmonization } \\
\text { and transparency of specific policies } \\
\text { across countries } \\
\text { - studies single standard or set of related } \\
\text { standards } \\
\text { - can be combined with welfare analysis }\end{array}$ & $\begin{array}{l}\text { Anders and Caswell (2009); Blind } \\
\text { et al. (2013); Czubala et al. (2009); } \\
\text { Disdier et al. (2008); Drogué and } \\
\text { DeMaria (2012); Fontagné et al. } \\
\text { (2005) ; Ghazalian et al. (2012); } \\
\text { Henry de Frahan (2006); } \\
\text { Jayasinghe et al. (2010); Lejarraga } \\
\text { et al. (2013); Tran et al. (2012); } \\
\text { Vancauteren and Henry de Frahan } \\
\text { (2011); Winchester et al. (2012); } \\
\text { Xiong and Beghin (2012); }\end{array}$ \\
\hline \multicolumn{3}{|c|}{ Impact on societal welfare with partial equilibrium models } \\
\hline $\begin{array}{l}\text { Studies on the welfare } \\
\text { impact of NTM regimes } \\
\text { allowing for potential } \\
\text { market imperfection }\end{array}$ & $\begin{array}{l}\text { - can be combined with econometric } \\
\text { estimates or calibrated } \\
\text { - includes external effect or asymmetric } \\
\text { information and risk of external effect } \\
\text { - welfare includes suppliers, users, and } \\
\text { external effects } \\
\text { - NTMs can be trade enhancing or not } \\
\text { and welfare enhancing or not }\end{array}$ & $\begin{array}{l}\text { Disdier and Marette (2010), } \\
\text { (2012); James and Anderson } \\
\text { (1998); Orden and Romano (1996); } \\
\text { Peterson and Oden (2008); Yue and } \\
\text { Beghin (2009); Yue et al. (2006); } \\
\text { Xiong and Beghin (2014); Van } \\
\text { Tongeren et al. (2009); } \\
\text { Risk analysis: Wilson and Anton } \\
\text { (2006) }\end{array}$ \\
\hline $\begin{array}{l}\text { Micro-level approaches } \\
\text { Studies on the effect of } \\
\text { public standards on firms' } \\
\text { export performance } \\
\end{array}$ & $\begin{array}{l}\text { - difficult to identify causality } \\
\text { - in line with recent focus on firm } \\
\text { heterogeneity in trade literature }\end{array}$ & Chen et al. (2008) \\
\hline
\end{tabular}


Table 2: Summary of the empirical literature on the trade, supply chain and welfare effects of private standards

Focus and approach $\quad$ Strengths / weaknesses $\quad$ Examples

\section{Export performance of companies}

Studies on the impact of adoption of private standards on firms' export performance
- cross-sectional \& panel data evidence

- studies on individual standards and as well as studies comparing different private standards
Colen et al. (2012); Henson et al. (2011); Otsuki (2011); Schuster and Maertens (2013a, 2015); VolpeMartincus et al. (2010)

\begin{tabular}{|c|c|c|}
\hline \multicolumn{3}{|c|}{ In/exclusion of smallholder farmers } \\
\hline $\begin{array}{l}\text { General studies documenting } \\
\text { the in/exclusion of } \\
\text { smallholders in high- } \\
\text { standards supply chains } \\
\text { Specific studies analyzing } \\
\text { the effect of standards on } \\
\text { sourcing from smallholders }\end{array}$ & $\begin{array}{l}\text { - no causal effect assessed } \\
\text { - dynamics over longer periods assessed } \\
\text { - evidence from a wide range of cases } \\
\text { - causal effects assessed } \\
\text { - cross-sectional and panel data } \\
\text { evidence } \\
\text { - studies on single standards and } \\
\text { comparative studies }\end{array}$ & $\begin{array}{l}\text { Dolan and Hunphrey (2000); Jaffee } \\
\text { and Masakure (2005); Reardon and } \\
\text { Berdegué (2002); Supervie and } \\
\text { Vagneron (2013); and many others } \\
\text { Schuster and Maertens (2013b); } \\
\text { Van Herck and Swinnen (2014) }\end{array}$ \\
\hline \multicolumn{3}{|c|}{ Impact of standards on farmers’ welfare } \\
\hline $\begin{array}{l}\text { General studies on the } \\
\text { impact of inclusion in high- } \\
\text { standards supply chains }\end{array}$ & $\begin{array}{l}\text { - effects confounded with other issues } \\
\text { such as contract-farming and export } \\
\text { market access } \\
\text { - based on cross-sectional data } \\
\text { - effects on various outcomes, including } \\
\text { income, poverty, happiness, farm } \\
\text { productivity, produce quality, } \\
\text { technology }\end{array}$ & $\begin{array}{l}\text { Maertens \& Swinnen (2009); } \\
\text { Dedehouanou et al. (2013); Rao \& } \\
\text { Qaim (2011); Negash \& Swinnen } \\
\text { (2013); Rao et al. (2012); Minten et } \\
\text { al. (2009); Dries \& Swinnen (2004, } \\
\text { 2010); Gow et al. (2000); Noev et } \\
\text { al. (2009); }\end{array}$ \\
\hline $\begin{array}{l}\text { Specific studies on the } \\
\text { impact of a single standard }\end{array}$ & $\begin{array}{l}\text { - effects singled out } \\
\text { - based on cross-sectional data } \\
\text { - income, poverty and health effects }\end{array}$ & $\begin{array}{l}\text { Asfaw et al (2009, 2010a\&b); } \\
\text { Handschuch et al. (2003); } \\
\text { Holzapfel \& Wollni (2014) }\end{array}$ \\
\hline $\begin{array}{l}\text { Specific and comparative } \\
\text { studies on the impact of } \\
\text { multiple standards }\end{array}$ & $\begin{array}{l}\text { - effects singled out and compared } \\
\text { across standards } \\
\text { - based on cross-sectional data } \\
\text { - income and poverty effects }\end{array}$ & $\begin{array}{l}\text { Chiputwa et al (2015); Hansen \& } \\
\text { Trifkovic (2014) }\end{array}$ \\
\hline \multicolumn{3}{|c|}{ Impact of standards on workers' welfare } \\
\hline $\begin{array}{l}\text { General studies on the } \\
\text { impact of employment in } \\
\text { high-standard sectors }\end{array}$ & $\begin{array}{l}\text { - no direct effect of standards } \\
\text { - based on cross-sectional data } \\
\text { - effects on various outcomes, including } \\
\text { income, poverty, female } \\
\text { empowerment, child schooling, } \\
\text { fertility }\end{array}$ & $\begin{array}{l}\text { Maertens \& Swinnen (2009); } \\
\text { Maertens et al (2011); Maertens \& } \\
\text { Verhofstadt (2014); Mano et al. } \\
\text { (2011); Van den Broeck \& } \\
\text { Maertens (2014); Trivkovic (2014) }\end{array}$ \\
\hline $\begin{array}{l}\text { Specific studies on the } \\
\text { impact of standards on } \\
\text { worker welfare }\end{array}$ & $\begin{array}{l}\text { - effects singled out } \\
\text { - cross-sectional and panel data studies } \\
\text { - studies on single standards and } \\
\text { comparative studies }\end{array}$ & $\begin{array}{l}\text { Barrientos et al. (2003); Nelson et } \\
\text { al. (2007); Ehlert et al. (2014); } \\
\text { Rijsgaard \& Gibbon (2014); } \\
\text { Schuster \& Maertens (2014) }\end{array}$ \\
\hline
\end{tabular}

